\title{
Urban tourism: the growing role of VFR and immigration
}

\author{
Tom Griffin and Frederic Dimanche
}

\begin{abstract}
Purpose - The purpose of this paper is to offer some insights into the future of urban tourism with particular consideration given to immigration and visiting friends and relatives (VFR) travel. The discussion highlights the fact that cities are increasingly home to immigrants and transitory residents who host visitors, blurring resident-visitor distinctions, with implications for cultural and economic development, and tourism practitioners. These trends are highlighted, and discussions relating to the future are offered.

Design/methodology/approach - This discussion is based on a literature review and a conceptual approach. Findings - The number of immigrants to cities keeps growing. These immigrants are shaping their new communities and changing local culture. They contribute to increased tourism through generating VFR travel and creating new tourist attractions.

Research limitations/implications - The implications of VFR and immigration on urban tourism are most visible in large urban centers that are major points of entry into a country and international magnets. They are not, however, limited to big cities.

Practical implications - There are potential implications for municipal governments and destination marketers to consider how cultural development and the touristic promotion of the city overlap with areas and direction for possible partnerships with community groups.

Social implications - This paper promotes the idea that for immigrants, to experience their communities through hosting VFR has positive social implications in terms of integration and cultural development.

Originality/value - This paper discusses a topic rarely addressed the impact of VFR and immigration on shaping urban tourism.
\end{abstract}

Keywords Tourism, Immigration, City, Urban, VFR

Paper type Viewpoint

\section{Introduction}

Urban centers are now home to the majority of the global population. The forecast is for this trend to continue as increasing immigration drives urban population growth (International Organization for Migration, 2015; World Health Organization, 2016). With diversifying populations, the culture, infrastructure, trade and travel flows of cities are evolving and expanding (Dwyer et al., 2014). Simply put, the world is becoming more urban, with greater diversity in populations living in the same areas, creating burgeoning and increasingly cosmopolitan metropolises whose residents have expanding ties and networks across the globe.

One tourism-related implication of this rising urbanization and immigration is the increasing demand for travel among disparate friends and family members. This phenomenon is broadly conceptualized as visiting friends and relatives (VFR) travel. Despite global growth, both in volume and market share (United Nations World Tourism Organization, 2000, 2016), VFR travel has been largely disregarded by researchers and misunderstood by city tourism organizations. The activity of VFR hosts and their visitors is therefore ever more relevant to urban centers and regions, as more residents arrive from diverse areas, increasing the cumulative social network of the urban population with implications for cultural and economic development.

Large urban centers are therefore already active VFR destinations. However, this paper aims to identify and demonstrate the importance of the links between urban places and VFR activity,
Tom Griffin is an

Assistant Professor and Frederic Dimanche is Professor and Director, both at the Ted Rogers School of Hospitality and Tourism Management, Ryerson University, Toronto, Canada.
Received 31 October 2016 Revised 21 March 2017 Accepted 18 April 2017

(C) Tom Griffin and

Frederic Dimanche. Published in Journal of Tourism Futures. Published by Emerald Publishing Limited. This article is published under the Creative Commons Attribution (CC BY 4.0) licence. Anyone may reproduce, distribute, translate and create derivative works of this article (for both commercial \& non-commercial purposes), subject to full attribution to the original publication and authors. The full terms of this licence may be seen at http://creativecommons.org/ licenses/by/4.0/legalcode 
and then argues that this type of travel will become more important for cities in the future. A review of urban tourism literature is followed by a discussion of trends and implications regarding immigration to cities. VFR travel is then discussed as a conceptual framework that helps identify links between resident, guest and community with implications for tourism marketing and business development, immigrant integration, and communal cultural development. Finally, the implications of future immigration patterns, consumption of travel and family demographics are considered regarding the ongoing importance of VFR for urban communities in the decades to come.

\section{Urban tourism}

Cities are central to much tourism activity. They are convenient and multi-layered destinations for travelers, and are in turn impacted by visitors in terms of economic, social and cultural development (Edwards et al., 2008). Edwards et al. (2008) suggest the term urban should refer to "busy, interactive built environment[s] purposely developed to meet the needs of many stakeholders" (p. 1035). Urban centers are distinct from rural areas in population, with greater volume and often more diverse residents, who for varying needs and desires live in comparatively close proximity (Page and Hall, 2003). Cities are typically more accessible to visitors than rural areas with better transportation and tourism infrastructure. Further, because of their diversity, cities are hubs that offer a greater variety of reasons for tourists to visit, including business and culture, and as gateways to other regional destinations (Edwards et al., 2008; Page and Hall, 2003).

Scholarly interest in urban tourism has certainly increased in recent years, but is still comparatively limited given its size and significance (Ashworth, 2003; Ashworth and Page, 2011; Page and Hall, 2003; Selby, 2004a). Much urban tourism research has considered visitor activity within specific destinations (Shaw and Williams, 1994), produced within a discourse of marketing and regeneration, marginalizing cultural and social implications (Selby, 2004b). This reflects the political nature of much urban destination marketing that is often influenced by the hotel sector (Ford and Peeper, 2009; Gartrell, 1988; Heeley, 2015; Pike, 2004; Wang, 2011), creating a discourse of "putting heads in beds" as a measure of success for many destination marketing organizations (DMOs) despite the growing diversity of stakeholders (Ford, 2008; Wang, 2011).

Tourism can transform cities, and is often directed by investment and policy development goals. loannides and Petridou (2016) argue that the neo-liberal shift in the USA (and experienced elsewhere) since the 1980s, and the subsequent lack of public funds, lead many city governments to pursue tourism as a tool for regeneration. However, there are concerns that the development inspired in this political environment created homogenized manifestations of "waterfront developments, repackaged culture and heritage, and café culture" (Maitland and Newman, 2009, p. 1) undermining local distinctiveness and smothering distinction. Tourism development should enhance resident quality of life through the development of cultural attractions made possible or enhanced by additional visitors, benefiting them psychologically and practically from the outcomes of tourism (Ashworth and Page, 2011). However, development instigated by the desire to attract temporary visitors and the economic benefits they bring risks inauthenticity and avoids genuine resident engagement on how their community should evolve (Heeley, 2015; Ioannides and Petridou, 2016).

\section{Immigration to urban areas}

Different countries and regions receive various groups of immigrants for different reasons including existing family connections, historical ties and a common language, immigration policies relating to labor and asylum, and political and economic links between countries (Bell et al. , 2010; Rigg et al., 2014; Skeldon, 2013). Historically, urban centers have attracted most of the immigrant population, and this is driving city populations upwards (Edwards et al., 2008; OECD, 2016; Seaton and Palmer, 1997). Globally there are around 3.9 billion people living in cities presently, with 6.3 billion forecast by 2050 (United Nations Department of Economic and Social Affairs, 2014). Immigrants are naturally drawn to cities as hubs of transportation, existing diaspora and employment opportunities (International Organization for Migration, 2015). In major 
global gateway cities, such as London, Toronto or New York, upwards of a third of the populations are immigrants, with urban centers in Asia and Africa generally showing lower, but ever increasing numbers (International Organization for Migration, 2015; Skeldon, 2013).

Immigrants bring their culture and increase cultural diversity in cities. New traditions, food, festivals and more add to urban vibrancy, producing new hybrid forms of culture that are distinct to the new immigrant community. Immigrant districts are traditional tourism attractions, and reflect the new waves of immigration from different diaspora to new neighborhoods across the city (Griffin and Dimanche, 2016). Most urban areas receive migrants who are seeking a peaceful life and employment opportunities unavailable in their own communities. International events and economic necessity shape immigration flows. For example, the current Syrian crisis has led to an influx of Syrian refugees to European cities. In the 1970s, the political situation in Southeast Asia contributed to heavy flows of Vietnamese, Laotian, and Cambodian immigrants to France and the USA. Host countries can open the door to immigration because they need a larger workforce. For example, fast growing economies in the 1960s such as France, Germany, the UK or Canada and the USA attracted immigrants from poorer countries. The job opportunities were in the urban areas of Europe, North America and other economically powerful regions.

Researchers have long studied the impact of immigration on cities and their labor markets, economy (e.g. James et al., 1998; Saiz, 2003) and crime (Ousey and Kubrin, 2009). Cities that are strategic in managing immigrants can benefit significantly through the provision of skills and labor, and cultural development that diversity brings (International Organization for Migration, 2015; OECD, 2016). As many developed nations' populations age, communities are competing for highly skilled, healthy and young immigrants to help develop industries and public services, and make contributions to the tax pool (Skeldon, 2013). Although recent political waves may contradict this, the opinion of international organizations remains that broadly speaking immigration brings positive impacts (International Organization for Migration, 2015).

\section{VFR travel}

A large number of trips worldwide are initiated by the desire to visit friends and relatives (Backer, 2007, 2010; Seaton, 1994). However, VFR has received comparatively little attention despite its substantial volume and importance to many travelers and communities. This is arguably due to the political nature of much destination marketing discourse (Backer, 2007, 2011; Lee et al., 2005; Morrison and O'Leary, 1995; Poel et al., 2006; Scheyvens, 2007; Seaton and Palmer, 1997; Seaton and Tagg, 1995). The term VFR typically refers to one of four common visitor categories: respondents to visitor surveys are asked for their self-reported trip purpose and ascribed to either VFR, pleasure, business, or other (Seaton, 1994). This conceptualization has been increasingly challenged, however, (Moscardo et al., 2000; Munoz et al., 2017), as trip purpose alone excludes visitors who state alternate reasons (e.g. pleasure and business) but stay with a friend or relative, spend time with a resident they know, or even visit other destinations on route to a friend or relative that would otherwise not be considered.

Backer (2011) argued for the inclusion of accommodation use in conceptualizing VFR travel. Griffin (2013) went further to suggest that VFR should "broadly refer to all tourism experiences that involve a prior personal relationship between a visitor and resident no matter the stated trip purpose, accommodation used, or activities engaged in" (p. 235). These more comprehensive understandings better allow the impact personal relationships between residents and their VFR to be considered. For example, the convention visitor who chooses one event over another because she can catch up with an old friend for dinner, or the vacationers who choose a trip across Canada so they can spend time with their relatives in a town along the way, or the regional benefits of VFR visitors and their hosts in urban centers choosing side trips to downtown and rural areas (Griffin, 2016; Griffin and Nunkoo, 2016); all of these examples, and more, would be excluded from VFR using the traditional trip purpose operationalization.

Not only is the volume of visitation generated through VFR underestimated, but the cultural and economic impacts on a destination are also distinct from other forms of tourism development. VFR is a more stable source of demand, with less seasonality and less significantly impacted by external threats (Griffin, 2013). Further, economic benefits are more widely dispersed across a 
community and not concentrated in a tourism core, benefitting a wider range of stakeholders, and creating demand that is more easily subsumed within the routine of a city. VFR is more consistent with local demand and interests as residents guide and interpret their surroundings (Shani and Uriely, 2012; Young et al., 2007), creating greater political and economic capital for residents in the development of their own communities and culture (Griffin, 2013). Residents as hosts also consume and co-create tourism with their guests (Andrades and Dimanche, 2014), taking vacation time to host, keeping their spending in the region, creating demand for cultural infrastructure that enables further tourism promotion (Griffin and Dimanche, 2016). VFR creates a context of leisure where disparate friends and relatives can reconnect affecting identity and well-being (Griffin, 2015; Humbracht, 2015), where visitors can receive an "authentic" experience that creates reliable and influential word-of-mouth (WOM) marketing (Litvin et al., 2008), and residents are more obliged to take a leisure view of their own community that can improve attachment and pride (Griffin, 2016).

The general disregard of VFR is at best a missed marketing opportunity. Worse, it is the exclusion of residents in shaping their community's image, that otherwise is skewed to attract supposedly high-yield visitors with little connection destination, affecting the direction of investment in related marketing and cultural infrastructure. VFR demand helps to retain a connection with residents and the production and consumption of culture and tourism (Caffyn, 2012; Mundt, 2011), avoiding the homogeneity and superficiality that other types of (urban) tourism development can create (loannides and Petridou, 2016).

\section{VFR and immigration}

VFR and immigration are closely connected (Williams and Hall, 2000), with implications for both communities and individuals. Cities with a large foreign population are likely to see flows of visitors from countries that were sources of immigration. As demand develops, and travel flows between the two communities are established, opportunities for further cultural connections, increased trade, and additional types of tourism open up (Dwyer et al., 2014). For immigrants who host, the VFR experience can inspire interaction with the new community in a leisure context, but importantly the experience is shared with someone who likely has familiar cultural understandings and mutual history. This has implications for immigrant hosts and their relationships with their visitors and new community.

VFR enables face-to-face interaction between host and guest, who can perform relationship roles, and demonstrate mutual care toward each other (Baumeister and Leary, 1995; Cohen and Wills, 1985). For recent immigrants, isolation and culture shock can be an issue (Mainil and Platenkamp, 2010), and the opportunity to spend quality time with a loved one or close friend can positively affect well-being after their guest has left (Griffin, 2015). Hosting can also shift the gaze of the immigrant resident, from newcomer to expert, and of the community as a place of residence to a place of leisure. Leisure participation in general has been found to help immigrant integration (e.g. Horolets, 2012; Lange et al., 2011; Rublee and Shaw, 1991; Stodolska and Livengood, 2006), and the added context of hosting a guest adds context to these experiences. Guiding a guest can help build attachment and pride for the host to the new community which becomes an essential and contextual backdrop to the personal relationship, establishing a sense of home through the collection of stories and souvenirs that bridge old and new worlds that endures beyond the visit itself (Humbracht, 2015; Lange et al., 2011; Larsen, 2008; Larsen et al., 2007). The integration of immigrants, their sense of belonging to the place and culture, and the community's positive response, adaptations and acceptance of new groups is vital for all of society to prosper (Frideres, 2008; International Organization for Migration, 2015), and hosting is consistent with these goals.

\section{VFR and urban communities}

Urban residents have often been viewed as the demand side of tourism (Ashworth and Page, 2011), but they are also an important component of supply for their own communities. Cities are natural VFR destinations because they often have large and diverse populations (e.g. Statistics Canada, 2015). 
There is overlap between VFR and the nature of urban populations. As a growing number of people live and work in multiple cities on a rotating basis (International Organization for Migration, 2015; OECD, 2016) and populations are made up of new or temporary residents who, to varying extents, treat their new communities as destinations to explore (Edwards et al., 2008; Griffin, 2016), the dichotomous view of resident and visitor becomes ever more blurred. Cities are therefore a "complex mix of 'intersecting mobilities'" (Maitland and Newman, 2009, p. 14), and the distinction between visitor and local is, in many cases, uninformed (Cohen and Cohen, 2012). Arbitrary definitions shape binary understandings of tourist and resident. A tourist is technically someone who stays for less than a year (Govers et al., 2008), and an immigrant someone who stays for a year or more (Skeldon, 2013). Although useful for measurement, many individuals will struggle to categorize themselves this simply; for example, international students, temporary workers, those seconded to a satellite office for a period of months, or who visit places on a regular but seldom frequency (Skeldon, 2013). Rigid distinctions between home and away, "extraordinary and ordinary, pleasure and boredom, liminality and rules, exotic others and significant others" (Larsen, 2008, p. 21) limit an appreciation for the lived realities of many. Many transitory and newcomer residents will attract and cause mobility to their cities, whether for short leisure-based trips, or more permanent migration. Mobile residents, of which urban areas are home to, create reason and demand for others to visit.

Ashworth (2003) asked urban tourism researchers to consider " ' [w] hat is particularly urban about urban tourism?' and; 'Which special characteristics of all or some cities are relevant to which kinds of tourism?'” (p. 147). Arguably the nature of residents' own mobilities and their relationships with others is a consistent and recognizable phenomenon at varying levels across cities. This three-way relationship between resident-visitor-community in VFR urban travel experiences challenges issues of homogenized neo-liberal tourism development and binary views resident-visitor (Heeley, 2015; Ioannides and Petridou, 2016). This is consistent with a shift in demand for post-fordist experiences (Mowforth and Munt, 2008; Page and Hall, 2003), with individualized and authentic experiences that accrue cultural capital (Bourdieu, 1986). VFR travel and its confluence with immigration may not strictly be a uniquely urban experience, but is predominantly consumed within and affects urban environments (Page and Hall, 2003).

\section{VFR and urban destinations in the future}

The following section draws together some key predictions that have implications for the rising importance of VFR-related travel for urban communities.

\section{Increasing immigration and new political environments}

Recent politics in Europe and the USA have seen pushes to slow immigration, but it is difficult to predict to what extent the intent and values that have fueled these political movements will endure and affect global migration into the future. Despite empirical evidence that demonstrates the generally positive impacts of migration on economies, it is vital to note that immigration is experienced differently within a country (OECD, 2016). Urban areas receive more immigrants, and governments are increasingly seeking ways to either encourage or require newcomers to settle away from the large metropolises to smaller urban areas (OECD, 2016). It is likely, therefore, that the overall volume of immigration will not be diminished in the future, but newcomers may be dispersed to a greater number of smaller urban centers. This will see VFR demand to a greater number of urban centers grow, both from source countries, but also between cities as immigrants travel domestically to visit each other.

\section{Nature of demand for VFR travel}

This changing political environment is also creating instability for the travel industries. For some, movement is increasingly restricted, and for others the desire for travel is reduced. Political instability within a destination harms the appeal of the place for vacation and convention visitors, and with present uncertainties within many source communities the desire for frivolous travel is also likely to be limited (Frommer, 2017; Rosenbloom, 2016; Sönmez, 1998). However, where demand for other types of travel may decline in times of uncertainty, VFR travel will persist, as "[c]opresent interaction remains [...] the fundamental mode of human intercourse 
and socialization" (Boden and Molotch, 1994, p. 258). The desire to spend time with loved ones does not dissipate because of the need for belonging, identity, and well-being (Baumeister and Leary, 1995; Cohen and Wills, 1985; Schänzel and Yeoman, 2015; Urry, 2002), and VFR demand overrides to a greater extent these issues that affect other more fluctuating types of tourism. Further, knowing a local as a host may help visitors feel extended comfort and security knowing they are being guided by someone they trust. The stronger the attachment to a destination the easier it is to convert potential visitors to actual, and personal connections with resident friends and relatives can be a powerful attraction and reason for repeat visits (Ashworth and Page, 2011). In these increasingly politically uncertain times may prove an important and stable source of demand for urban centers. If current political environments continue, and travel is either restricted or made less appealing, then VFR will become a more important part of urban destinations' activity.

\section{Evolution of the family}

The structure and nature of relationships among families is evolving and forecast to continue, with "most extended families [that] live geographically apart" (Schänzel and Yeoman, 2015, p. 142). Family travel is therefore an increasingly important and developing segment (Schänzel and Yeoman, 2015). As family members are often distant, it is not just demand for broadly speaking leisure-based travel, but mobility that enables the performance of social roles and exchange of social capital. For example, increasing numbers are living longer and healthier, and for grandparents to provide child care, they must now travel to do so. In many communities the number of people living alone has also increased, and due to advances in medicine and quality of life there are likely to be a growing number of people who will live alone in their older years, another predictor that VFR demand will remain and grow as people seek quality time and interaction with their distant loved ones (Hall and Ogden, 2003; Ortman et al., 2014). Further, family celebrations such as marriage or birthdays are also requiring travel to be made in order for distant friends and family to share milestones together (Backer and King, 2015; Schänzel and Yeoman, 2015). In addition, as the middle classes of many nations grow, particularly India and China, the context of strong family ties and immigration hold particular interest and implications for VFR travel from and within these new economies (Backer and King, 2015). Although not specific for urban areas, as cities expand and become more diverse the demand and opportunities for these types of travel experiences, and the multi-purpose travel opportunities they bring, will rise accordingly.

\section{Changing world order}

Looking even further ahead beyond the immediate future and potential impact of current immigration policies and environments is the changing world order. Many countries that are the source for much emigration around the world are also seeing a rising middle class and economic development, which are stimulating outbound tourism (Webster and Ivanov, 2015). Whereas the potential for vacation- and business-related travel has been often considered (Mariani et al., 2014; Smeral, 2010), the cultural and historical connections between countries that send and receive immigrants will influence all future travel flows (Webster and Ivanov, 2015). Cities that have been traditional destinations for immigrants from these developing economies and who already see cultural connections are likely to see a growing demand for VFR-related travel as middle classes increase.

\section{Climate change}

As impacts of climate change become more severe and frequent some are predicting that the price of transport will increase, with some calling for carbon rationing and limitations on air travel (Gössling et al., 2008; Higham et al., 2016; Peeters and Dubois, 2010). It is possible that in the future, unless significant changes in technology are made, excessive air travel could become less socially acceptable, more expensive and restricted. If this happens, VFR demand will become a much higher proportion of all travel. Cities with immigrants will likely become hubs for VFR visitors as distant friends and relatives use their limited air travel to see each other. Regions around cities that are accessible by other forms of transport could become more appealing as leisure destinations for urban VFR visitors and their hosts. Visitors in general are increasingly 
seeking multi-destination trip experiences for the variety, efficiency, and reduced risk of dissatisfaction (Lue et al., 1993), and immigrant hosts in urban destinations are already taking their guests to regional destinations as side trips (Griffin, 2016; Griffin and Nunkoo, 2016). If long-haul travel becomes limited or restricted, this type of multi-destination trip will become more prevalent.

\section{Implications for practitioners}

There are important implications for urban tourism practitioners. Initially, urban DMOs need to view tourism within the context of their communities. Even if the promotion of traditional leisure and convention tourism is the priority, viewing these travel patterns in isolation from other mobility flows is short-sighted. Urban DMOs should engage and work with other agencies that promote the destination reputation and image to other groups, whether this be trade missions, universities seeking international students, or other government agencies with international connections. The role of DMOs is shifting from marketing to communication (Heeley, 2015) and developing long-term awareness among all forms of mobility is vital. As an ever increasing proportion of residents are newcomers, the services, information and experiences they seek will overlap those traditionally provided for tourists. Traditional tourism marketing and services therefore have a substantial role to play in helping attract and integrate new residents. Conversely, engaging new residents has implications for tourism promotion and activity. A community with happy and engaged residents develops culture and a spirit of hospitality making it an appealing place to visit. Helping newcomers feel settled should be of primary interest to many agencies, but should also be important for urban DMOs regarding the image and reputation of their community.

Urban tourism practitioners should therefore be concerned with the quantity and quality of VFR-related experiences that happen in their community, and the actual and potential influence they have in furthering the destination image and awareness through personal and online networks. Policy makers and marketers should consider tourism not just as a promotion and development of experiences for outsiders, but also from a cultural development perspective (Edwards et al., 2008) that attempts to link "local urban social cohesion to economic growth and global competitiveness" (International Organization for Migration, 2015, p. 4). DMOs should partner with settlement agencies and companies, welcoming newcomers, encouraging them to invite and host friends and relatives. Populations are different from one city to another, but identifying the types of relationships that residents have with their distant networks, and who those networks include, will provide valuable insight into how experiences of the destination are produced and disseminated through WOM marketing.

\section{Conclusion}

This discussion offers some insights into the future of urban tourism. Simply put, cities are receiving more immigrants, from more places, for varying amounts of time, who are first exploring the city as newcomers, and hosting friends and relatives. When immigrants settle, their collective activity, behavior, and influence in turn affect the culture and tourism offerings made available for other visitors and residents alike. Their neighborhoods, restaurants and festivals, for example, often become tourist attractions. VFR is important for cities; first, it brings more people to the destination. Second, it spreads authentic WOM marketing. Third, it encourages residents to become familiar, engaged with or refresh their attachment and awareness of their community as a place to explore and spend leisure, co-creating experiences and culture that affect the experiences of other tourists. Finally, the long-term impacts of hosting for immigrants are likely to make them feel more comfortable and settled. Adopting binary distinctions between residential and tourism development risks blunting culture and residents' voice. The future of urban tourism will see the blurring of resident-visitor continue, and immigrant hybrid culture will offer distinct culture and narratives for cities. Urban DMOs need to better identify and feature cultural assets resulting from immigrant populations, but need to remain true to the authentic voice of the local communities; and understanding and engaging VFR and the relationship between residents and visitors will help. 


\section{References}

Andrades, L. and Dimanche, F. (2014), "Co-creation of experience value: a tourist behavior approach", in Prebensen, N., Chen, J. and Uysal, M. (Eds), Creating Experience Value in Tourism, CABI, London, pp. 95-112.

Ashworth, G. and Page, S.J. (2011), "Urban tourism research: recent progress and current paradoxes", Tourism Management, Vol. 32 No. 1, pp. 1-15.

Ashworth, G.J. (2003), “Urban tourism: still an imbalance in attention”, in Cooper, C. (Ed.), Classic Reviews in Tourism, Channel View, Clevedon, pp. 143-63.

Backer, E. (2007), "VFR travel: an examination of the expenditures of VFR travellers and their hosts", Current Issues in Tourism, Vol. 10 No. 4, pp. 366-77.

Backer, E. (2011), "VFR travel: it is underestimated", Tourism Management, Vol. 33 No. 1, pp. 74-9.

Backer, E. and King, B. (2015), "Local impacts, global prospects: the future of VFR travel”, in Backer, E. and King, B. (Eds), Visiting Friends \& Relatives: Exploring the VFR Phenomenon, Channel View, Bristol, pp. 207-18.

Backer, E.R. (2010), "Opportunities for commercial accommodation in VFR travel", International Journal of Tourism Research, Vol. 12 No. 4, pp. 334-54.

Baumeister, R.F. and Leary, M.R. (1995), "The need to belong: desire for interpersonal attachments as a fundamental human motivation”, Psychological Bulletin, Vol. 117 No. 3, pp. 497-529.

Bell, S., Alves, S., de Oliveira, E.S. and Zuin, A. (2010), "Migration and land use change in Europe: a review", Living Reviews in Landscape Research, Vol. 4 No. 2, pp. 1-49, doi: 10.12942//rrr-2010-2.

Boden, D. and Molotch, H. (1994), "The compulsion of proximity", in Friedland, R. and Boden, D. (Eds), NowHere: Space, Time and Modernity, University of California, Berkeley, CA, pp. 257-86.

Bourdieu, P. (1986), "The forms of capital", in Richardson, J.G. (Ed.), Handbook of Theory and Research for the Sociology of Education, Greenwood Press, New York, NY, pp. 241-58.

Caffyn, A. (2012), "Advocating and implementing slow tourism", in Singh, T.V. (Ed.), Critical Debates in Tourism, Channel View, Bristol, pp. 373-9.

Cohen, E. and Cohen, S.A. (2012), "Current sociological theories and issues in tourism", Annals of Tourism Research, Vol. 39 No. 4, pp. 2177-202.

Cohen, S. and Wills, T.A. (1985), "Stress, social support, and the buffering hypothesis", Psychological Bulletin, Vol. 98 No. 2, pp. 310-57.

Dwyer, L., Seetaram, N., Forsyth, P. and King, B. (2014), "Is the migration-tourism relationship only about VFR?", Annals of Tourism Research, Vol. 46 No. 3, pp. 130-43, doi: 10.1016/j.annals.2014.03.009.

Edwards, D., Griffin, T. and Hayllar, B. (2008), “Urban tourism research: developing an agenda”, Annals of Tourism Research, Vol. 35 No. 4, pp. 1032-52, available at: http://dx.doi.org.proxy.lib.uwaterloo.ca/10.1016/ j.annals.2008.09.002

Ford, R.C. (2008), "Chasing MICE and fellow travelers: a history of the convention and visitor bureau industry", Journal of Management History, Vol. 14 No. 2, pp. 128-43.

Ford, R.C. and Peeper, W.C. (2009), "Destination marketing organizations: convention and visitors bureaus", in Jamal, T. and Robinson, M. (Eds), The Sage Handbook of Tourism Studies, Sage, Thousand Oaks, CA, pp. $432-47$.

Frideres, J. (2008), "Creating an inclusive society: promoting social integration in Canada", in Frideres, J., Burstein, M. and Biles, J. (Eds), Immigration and Integration in Canada in the Twenty-First Century, Queen's University, Kingston, pp. 77-101.

Frommer, A. (2017), “'Mounting signs' that trump policies hurting US tourism, say industry groups”, CBC News, March, available at: www.cbc.ca/news/business/trump-us-travel-slump-1.4008256 (accessed 3 April 2017).

Gartrell, R.B. (1988), Destination Marketing for Convention and Visitor Bureaus, Hunt Publishing, lowa.

Gössling, S., Peeters, P. and Scott, D. (2008), "Consequences of climate policy for international tourist arrivals in developing countries”, Third World Quarterly, Vol. 29 No. 5, pp. 873-901. 
Govers, R., Van Hecke, E. and Cabus, P. (2008), "Delineating tourism: defining the usual environment", Annals of Tourism Research, Vol. 35 No. 4, pp. 1053-73.

Griffin, T. (2013), "Visiting friends and relatives tourism and implications for community capital", Journal of Policy Research in Tourism, Leisure and Events, Vol. 5 No. 3, pp. 233-51.

Griffin, T. (2015), "Considering the experience of hosting friends and relatives for immigrants", in Backer, E. and King, B. (Eds), Visiting Friends \& Relatives: Exploring the VFR Phenomenon, Channel View, Bristol, pp. 73-86.

Griffin, T. (2016), "Immigrant hosts and intra-regional travel”, Tourism Geographies, Vol. 19 No. 1, pp. 1-19.

Griffin, T. and Dimanche, F. (2016), "Comment les immigrés contribuent-ils au tourisme urbain: Le cas de Toronto (how do immigrants contribute to urban tourism: the case of Toronto)", paper presented at the Rendez-Vous Champlain 2016 conference, Montreal, May.

Griffin, T. and Nunkoo, R. (2016), "Paid accommodation use of international VFR multi-destination travellers", Tourism Review, Vol. 71 No. 2, pp. 90-104.

Hall, R. and Ogden, P.E. (2003), "The rise of living alone in Inner London: trends among the population of working age", Environment and Planning, Vol. 35 No. 5, pp. 871-88.

Heeley, J. (2015), Urban Destination Marketing in Contemporary Europe: Uniting Theory and Practice, Channel View, Bristol.

Higham, J., Cohen, S.A., Cavaliere, C.T., Reis, A. and Finkler, W. (2016), "Climate change, tourist air travel and radical emissions reduction”, Journal of Cleaner Production, Vol. 111, Part B, pp. 336-47, doi: 10.1016/j. jclepro.2014.10.100.

Horolets, A. (2012), "Migrants' leisure and integration", Instytut Spraw Publicznych, Warszawa, available at: www.isp.org.pl/uploads/filemanager/pdf/Horolets.pdf (accessed 20 September 2016).

Humbracht, M. (2015), "Reimagining transnational relations: the embodied politics of visiting friends and relatives mobilities", Population, Space and Place, Vol. 21 No. 7, pp. 640-53.

International Organization for Migration (2015), "World migration report", International Organization for Migration, available at: http://publications.iom.int/system/files/wmr2015_en.pdf

Ioannides, D. and Petridou, E. (2016), "Contingent neoliberalism and urban tourism in the United States", in Mosedale, H. (Ed.), Neoliberalism and the Political Economy of Tourism, Routledge, New York, NY, pp. 21-36.

James, F., Romig, J. and Swanzig, P. (1998), "The effects of immigration on urban communities", Cityscape: A Journal of Policy Development and Research, Vol. 3 No. 3, pp. 171-92.

Lange, E., Vogels, P. and Jamal, Z. (2011), "Learning a language, learning the land: newcomers, parks, and language learning research and evaluation report", Alberta Tourism, Parks and Recreation, Edmonton, AB, September, available at: www.albertaparks.ca/media/3813539/learning_a_language_learning_the_land_-_ newcomers_parks__language_learning.pdf (accessed 20 September 2016).

Larsen, J. (2008), "De-exoticizing leisure travel”, Leisure Studies, Vol. 27 No. 1, pp. 21-34.

Larsen, J., Urry, J. and Axhausen, K.W. (2007), "Networks and tourism: mobile social life", Annals of Tourism Research, Vol. 34 No. 1, pp. 244-62.

Lee, G., Morrison, A.A., Lheto, X.Y., Webb, J. and Reid, J. (2005), "VFR: is it really marginal? A financial consideration of French overseas travellers", Journal of Vacation Marketing, Vol. 11 No. 4, pp. 340-56.

Litvin, S.W., Goldsmith, R.E. and Pan, B. (2008), "Electronic word-of-mouth in hospitality and tourism management", Tourism Management, Vol. 29 No. 3, pp. 458-68.

Lue, C.C., Crompton, J.L. and Fesenmaier, D.R. (1993), "Conceptualization of multi-destination pleasure trips", Annals of Tourism Research, Vol. 20 No. 2, pp. 289-301.

Mainil, T. and Platenkamp, V. (2010), "Narrative analysis as a tool for contextual tourism research: an exploration", Tourism Culture and Communication, Vol. 10 No. 1, pp. 59-75.

Maitland, R. and Newman, P. (2009), World Tourism Cities: Developing Tourism off the Beaten Track, Routledge, New York, NY.

Mariani, M.M., Buhalis, D., Longhi, C. and Vitouladiti, O. (2014), "Managing change in tourism destinations: key issues and current trends", Journal of Destination Marketing and Management, Vol. 2 No. 4, pp. 269-72. 
Morrison, A.M. and O'Leary, J.T. (1995), "The VFR market: desperately seeking respect”, Journal of Tourism Studies, Vol. 6 No. 1, pp. 2-5.

Moscardo, G., Pearce, P., Morrison, A., Green, D. and O'Leary, J.T. (2000), "Developing a typology for understanding visiting friends and relatives markets", Journal of Travel Research, Vol. 38 No. 3, pp. 251-9.

Mowforth, M. and Munt, I. (2008), Tourism and Sustainability, 3rd ed., Routledge, London.

Mundt, J.W. (2011), Sustainable Tourism: Reconsidering a Concept of Vague Policies, Erich Schmidt Verlag, Berlin.

Munoz, J., Griffin, T. and Humbracht, M. (2017), “Towards a new definition for 'visiting friends and relatives' ", International Journal of Tourism Research, pp. 1-9, doi: 10.1002/jtr.2110.

OECD (2016), "International migration outlook 2016", available at: www.keepeek.com/Digital-AssetManagement/oecd/social-issues-migration-health/international-migration-outlook-2016_migr_outlook-20 16-en\#page15 (accessed 20 September 2016).

Ortman, J.M., Velkoff, V.A. and Hogan, H. (2014), "An aging nation: the older population in the United States", US Department of Commerce Economics and Statistics Administration: US Census Bureau, Washington DC, available at: https://pdfs.semanticscholar.org/9e8d/9dc95a5130fa4fd0eb808b5c888e628c2023.pdf (accessed 20 September 2016).

Ousey, G.C. and Kubrin, C.E. (2009), "Exploring the connection between immigration and violent crime rates in US cities 1980-2000", Social Problems, Vol. 56 No. 3, pp. 447-73.

Page, S. and Hall, C.M. (2003), Managing Urban Tourism, Prentice Hall, London.

Peeters, P. and Dubois, G. (2010), "Tourism travel under climate change mitigation constraints", Journal of Transport Geography, Vol. 18 No. 3, pp. 447-57.

Pike, S. (2004), Destination Marketing Organisations, Elsevier, New York, NY.

Poel, P., Masurel, E. and Nijkamp, P. (2006), "The importance of friends and relations in tourist behaviour: a case study of heterogeneity in Surinam", in Giaoutzi, M. and Nijkamp, P. (Eds), Tourism and Regional Development: New Pathways, Ashgate, Burlington, VT, pp. 219-38.

Rigg, J., Nguyen, T.A. and Luong, T.T.H. (2014), "The texture of livelihoods: migration and making a living in Hanoi”, The Journal of Development Studies, Vol. 50 No. 3, pp. 368-82.

Rublee, C.B. and Shaw, S.M. (1991), "Constraints on the leisure and community participation of immigrant women: implications for social integration”, Loisir Et Societe, Vol. 14 No. 1, pp. 133-50.

Rosenbloom, S. (2016), "What impact will trump have on tourism?", The New York Times, November, available at: www.nytimes.com/2016/11/10/travel/trump-travel-tourism.html?_r=0 (accessed 3 April 2017).

Saiz, A. (2003), "The impact of immigration on American cities: an introduction to the issues", Business Review, Vol. 4, pp. 14-23, available at: www.phil.frb.org/-/media/research-and-data/publications/ business-review/2003/q4/brq403asaiz.pdf

Schänzel, H.A. and Yeoman, I. (2015), "Trends in family tourism”, Journal of Tourism Futures, Vol. 1 No. 2, pp. 141-7.

Scheyvens, R. (2007), "Poor cousins no more valuing the development potential of domestic and diaspora tourism", Progress in Development Studies, Vol. 7 No. 4, pp. 307-25.

Seaton, A.V. (1994), "Are relatives friends? Reassessing the VFR category in segmenting tourism markets", in Seaton, A.V. (Ed.), Tourism: The State of the Art, Wiley, Chichester, pp. 316-21.

Seaton, A.V. and Palmer, C. (1997), "Understanding VFR tourism behaviour: the first five years of the United Kingdom tourism survey", Tourism Management, Vol. 18 No. 6, pp. 345-55.

Seaton, A.V. and Tagg, S. (1995), "Disaggregating friends and relatives in VFR tourism research: the Northern Ireland evidence 1991-1993”, Journal of Tourism Studies, Vol. 6 No. 1, pp. 6-18.

Selby, M. (2004a), "Consuming the city: conceptualizing and researching urban tourist knowledge", Tourism Geographies, Vol. 6 No. 2, pp. 186-207.

Selby, M. (2004b), Understanding Urban Tourism: Image, Culture and Experience, IB Tauris, London.

Shani, A. and Uriely, N. (2012), "VFR tourism: the host experience", Annals of Tourism Research, Vol. 39 No. 1, pp. 421-40. 
Shaw, G. and Williams, A.M. (1994), Critical Issues in Tourism: A Geographical Perspective, Blackwell, Oxford.

Skeldon, R. (2013), "Global migration: demographic aspects and its relevance for development", available at: www.un.org/esa/population/meetings/EGM_MigrationTrends/UNNewYork-globmigpowerpoint_SH.pdf (accessed 20 September 2016).

Smeral, E. (2010), "Impacts of the world recession and economic crisis on tourism: forecasts and potential risks", Journal of Travel Research, Vol. 49 No. 1, pp. 31-8.

Sönmez, S.F. (1998), "Tourism, terrorism, and political instability”, Annals of Tourism Research, Vol. 25 No. 2 , pp. 416-56.

Statistics Canada (2015), "The Canadian population in 2011: population counts and growth", Statistics Canada, Ottawa, available at: www12.statcan.gc.ca/census-recensement/2011/as-sa/98-310-x/98310-x2011001-eng.cfm (accessed 20 September 2016).

Stodolska, M. and Livengood, J.S. (2006), "The influence of religion on the leisure behavior of immigrant muslims in the United States”, Journal of Leisure Research, Vol. 38 No. 3, pp. 293-320.

United Nations Department of Economic and Social Affairs (2014), "World urbanization prospects", United Nations, New York, NY, available at: https://esa.un.org/unpd/wup/Publications/Files/WUP2014Highlights.pdf (accessed 20 September 2016).

United Nations World Tourism Organization (2000), "Tourism highlights edition 2000”, UNWTO, Madrid, available at: www.e-unwto.org/doi/book/10.18111/9789284403745 (accessed 21 February 2017).

United Nations World Tourism Organization (2016), "Tourism highlights edition 2016", UNWOT, Madrid, available at: www.e-unwto.org/doi/book/10.18111/9789284418145 (accessed 21 February 2017).

Urry, J. (2002), "Mobility and proximity", Sociology, Vol. 36 No. 2, pp. 255-74.

Wang, Y. (2011), "Destination marketing and management: scope, definition and structures", in Wang, Y. and Pizam, A. (Eds), Destination Marketing and Management: Theories and Applications, CABI, Cambridge, MA, pp. 1-20.

Webster, C. and Ivanov, S. (2015), "Geopolitical drivers of future tourist flows", Journal of Tourism Futures, Vol. 1 No. 1 , pp. 58-68.

Williams, A.M. and Hall, C.M. (2000), "Tourism and migration: new relationships between production and consumption”, Tourism Geographies, Vol. 2 No. 1, pp. 5-27.

World Health Organization (2016), "Global report on urban health: equitable, healthier cities for sustainable development", Kobe and Geneva, available at: www.who.int/kobe_centre/measuring/urban-global-report/ ugr_full_report.pdf?ua=1 (accessed 20 September 2016).

Young, C.A., Corsun, D.L. and Baloglu, S. (2007), "A taxonomy of hosts visiting friends and relatives", Annals of Tourism Research, Vol. 34 No. 2, pp. 497-516.

\section{Corresponding author}

Tom Griffin can be contacted at: tom.griffin@ryerson.ca

For instructions on how to order reprints of this article, please visit our website:

www.emeraldgrouppublishing.com/licensing/reprints.htm

Or contact us for further details: permissions@emeraldinsight.com 